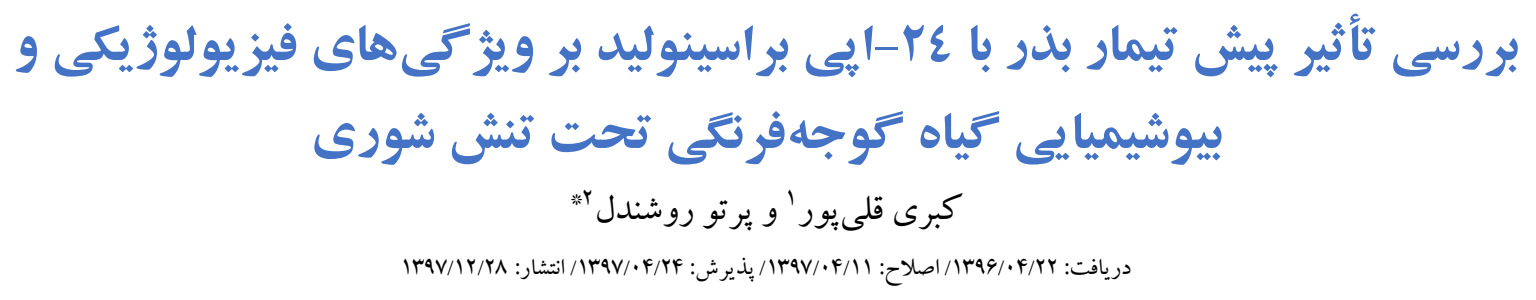

$$
\begin{aligned}
& \text { اخروه زيست شناسى، دانشكده علوم، دانشكاه شهر كرد، شهر كرد، ايران } \\
& \text { rكروه زراعت، دانشكده كشاورزى، دانشگاه شهر كرد، شهر كرد، ايران دان } \\
& \text { proshandel@sku.ac.ir : مسئول مكاتبات" }
\end{aligned}
$$

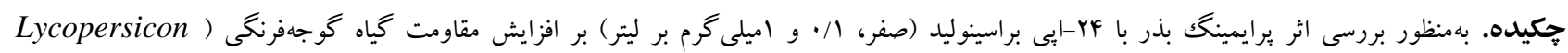
(esculentum Mill.

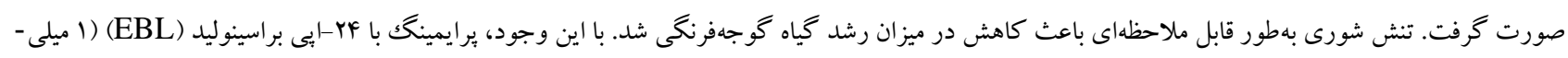

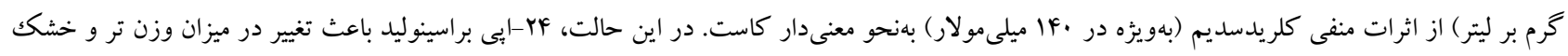

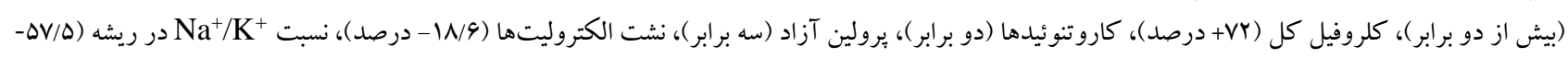

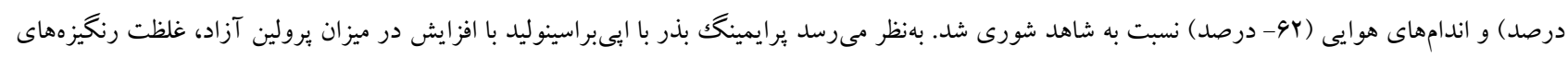

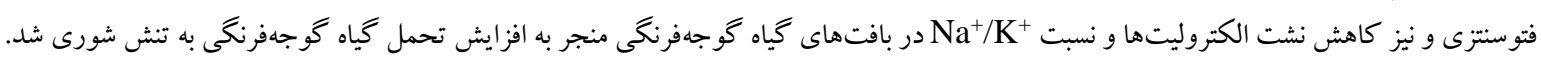

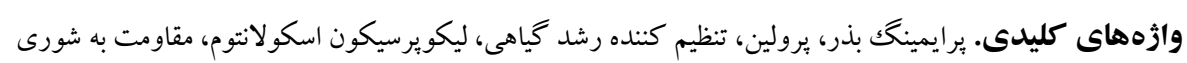

\title{
Effects of seed pretreatment with 24-brassinolide on physiological and biochemical characters in tomato plants under salt stress
}

Kobra Gholipoor ${ }^{1} \&$ Parto Roshandel ${ }^{2 *}$

Received 13.07.2017/ Revised02.07.2018/ Accepted 15.07.2018/ Published 19.03.2019

\begin{abstract}
${ }^{1}$ Department of Biology, Faculty of Sciences, Shahrekord University, Shahrekord, Iran ${ }^{2}$ Department of Agronomy, Faculty of Agriculture, Shahrekord University, Shahrekord, Iran * Correspondent author: proshandel@sku.ac.ir
\end{abstract}

\begin{abstract}
In order to study the effects of seed priming with 24-epibrassinolide (EBL) $(0,0.1,1 \mathrm{mg} / \mathrm{l})$ on the increase of the tolerance of tomato plants (Lycopersicon esculentum Mill.) to salinity (0, 70 and $140 \mathrm{mM} \mathrm{NaCl}$ ), factorial experiments were conducted in a completely randomized design under greenhouse conditions. Results showed that salt stress significantly decreased the growth of tomato plants. However, priming with EBL (1 mg/l) significantly decreased the negative effects of $\mathrm{NaCl}$ (particularly at $140 \mathrm{mM}$ ). As a result, EBL increased the fresh and dry weights $(<2$ folds), total chlorophyll $(+72 \%)$, carotenoids $\left(+2\right.$ folds), free proline $\left(+3\right.$ folds), electrolyte leakage $(-18.6 \%), \mathrm{Na}^{+} / \mathrm{K}^{+}$in the roots $(-57.5 \%)$ and shoots $(-62 \%)$ compared with salinity control. It could be concluded that priming with epibrassinolide resulted in enhanced salt tolerance in tomato plants via increment in free proline, photosynthetic pigments and decrease in electrolyte leakage and $\mathrm{Na}^{+} / \mathrm{K}^{+}$ratio in the tissues.
\end{abstract}

Keywords. Lycopersicon esculentum, plant growth regulator, proline, salt tolerance, seed priming 
Bajguz \& ( محيطى مانند خشكى، شورى و فلزات سنگين گردد Hayat, 2009

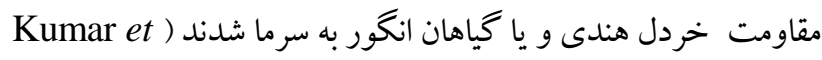
(al., 2010; Xi et al., 2013 بذر تربجه با عF بإبى براسينوليد باعث افزايش مقاومت كياهان اين

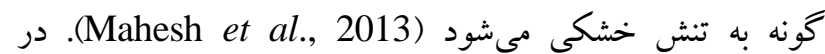

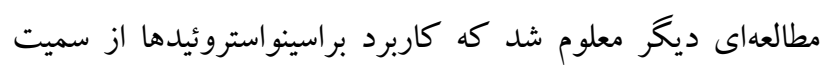
سرب، كادميم و روى در گياه تربجه مى كاهد ( Rao, 2007; Ramakrishna \& Rao, 2015 فاست تيمار بذر برنج با براسينواستروئيدها باعث تقويت سيستم

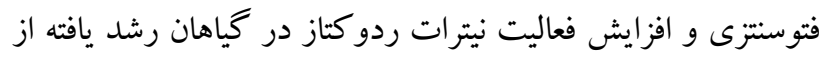
Anuradha \& Rao, ) جنين بذرهايى در شرايط شورى مى شود

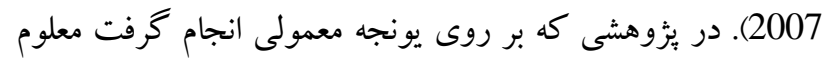

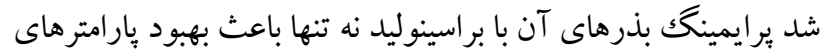

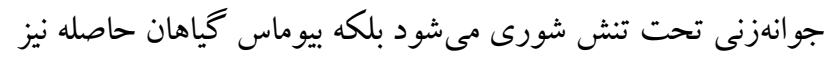
در شرايط شورى افزايش يافته است (Zhang et al., 2007). در تحقيق ديخرى خيساندن بذرهاى نخودفرنكى در محلول EBL باعث

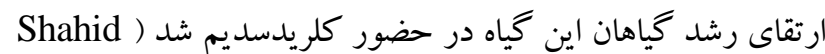
.(et al., 2011

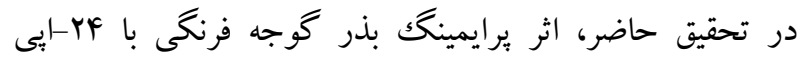
براسينوليد در افزايش مقاومت به شورى اين گياهان تحت تنش مذكور مورد بررسى قرار گرفته است.

\section{مواد و روشها}

آماده سازى و شرايط رشد

بذرهاى كوجه فرنكى (Lycopersicon esculentum Mill. DRW6208F منظور يرايمينگ از سه سطح YF

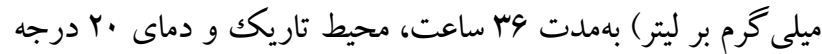
سانتيخر اد استفاده شد. پِ از آن بذرها براى جوانهزنى بر روى كاغذ

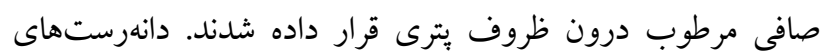
هفت روزه به كلدانهايى حاوى ماسه و برليت در كلخانه منتقل شدند. هر كلدان حاوى هاعدد گياه و هر تيمار شامل ب تكرار بود. شرايط

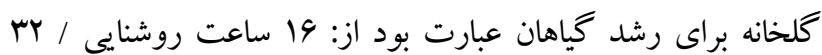

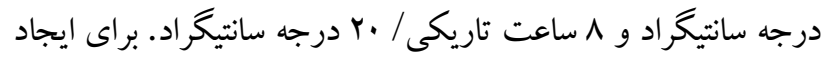

\section{مقام} كوجهفرنغى (Lycopersicon esculentum Mill.)

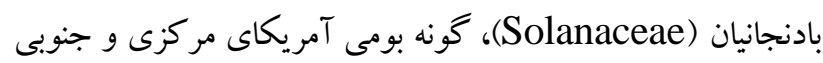

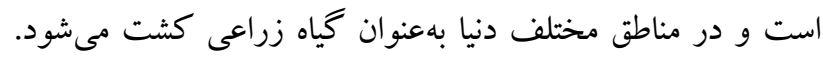

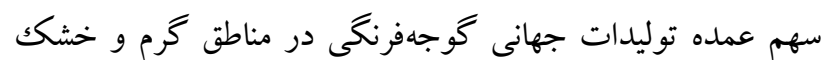
است. در ايران نيز مناطق وسيعى بلويزه در استانهاى بوشهر و

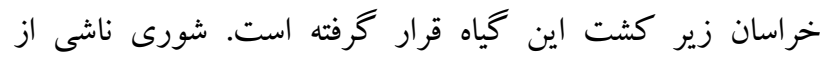
كلريدسديم از تنشهاى محيطى مضر و روبه افزايش بلويزه در مناطق خشك و نيمهشك دنيا محسوب مىشود كه توليد محصولات زراعى را دجار مخاطره جدى مىنمايد. در اين ميان، كياه گوجهفرنكى از جمله گياهان نسبتاً حساس به شورى است و و شورى آب يا خاكك در مراحل مختلف تكوين، رشد و توليد محصول اين گياه را تحت تأثير منفى قرار مىدهد. تاكنون روشهاى لترائ مختلفى براى مقاومسازى گياهان زراعى به تنش شورى معرفى شده

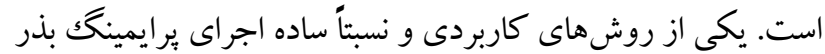

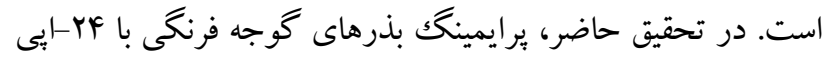
براسينوليد مورد مطالعه قرار گرفت. براسينواستروئيدها فيتوهورمون-

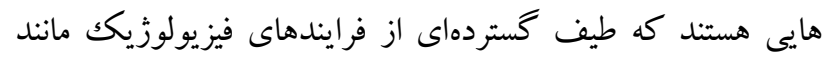

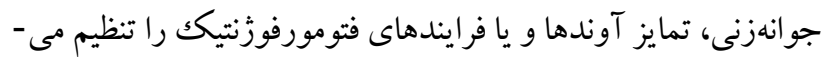
كنند (Gomes, 2011). اخيراً استفاده از اين دسته هورمونها درو

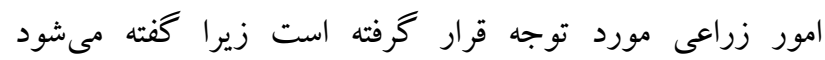

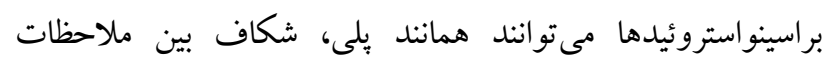

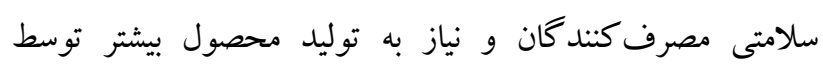

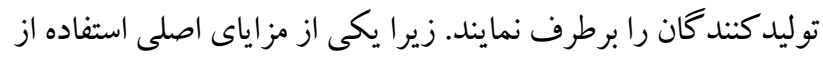

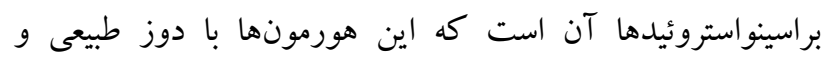

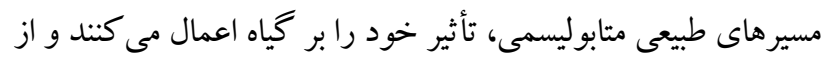
اين لحاظ كمترين تأثير مخاطرهانگيز را در اكوسيستمهاى طبيعى به دنبال خواهند داشت (Khripach et al., 2000). به عنوان مثال كزارش شده است كه استفاده از براسينواستروئيدها بر روى گياه

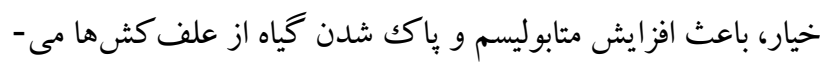

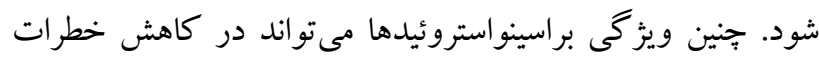
ناشى از سموم كشاورزى براى صيفىجاتى كه بهصورت

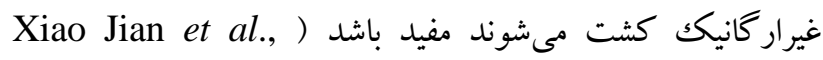
2009). از طرفى، روشن شده است كه كاربرد خارجى براسينواستروئيدها مىتواند باعث افزايش مقاومت گياه به تنشهاى 
هدايت = C C C $C_{1}$ الكتريكى محلول بعد از جوش

\section{تعيين ميزان يونهاى سديم و يتاسيم}

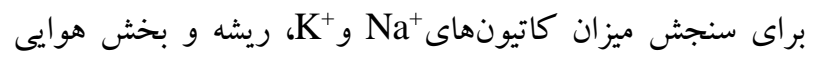

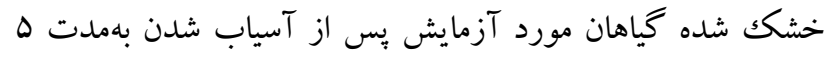
ساعت درون كوره و در دماى •هه درجه سانتيخر اد قرار داده شدند.

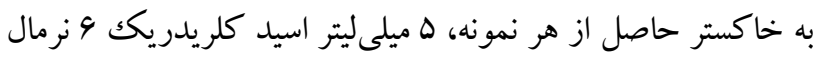
اضافه و حرارت داده شد. پس از صاف كردن نمونهها با كاغذ صافى، حجم محلول صاف شده با افزودن آب مقطر به ب. . ا ميلى ليتر رسانده شد. غلظت يونهاى سديم، يتاسيم با فليم فتومترى اندازهكيرى شد.

تجزيه و تحليل آمارى آزمايش ها در قالب طرح كاملا تصادفى و بهصورت فاكتوريل بـهـ

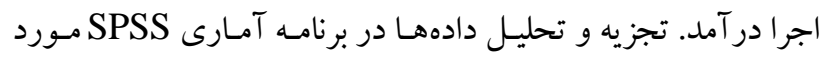

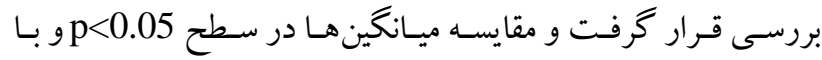

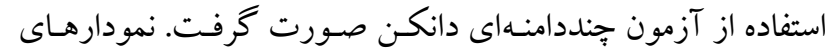
مربوطه با استفاده از برنامه Excel رسم شد شد.

نتايج تحليل دادهها حاكى از آن بود كه تنش شورى در هر دو سطح،

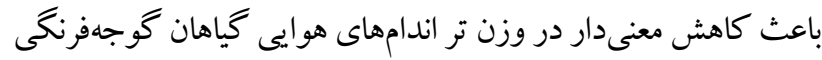

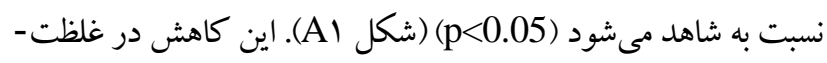

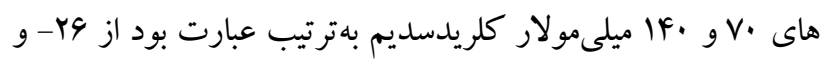

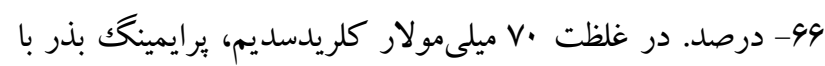
EBL

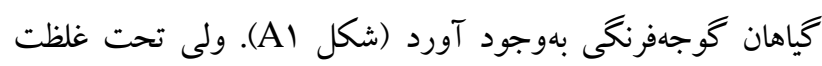

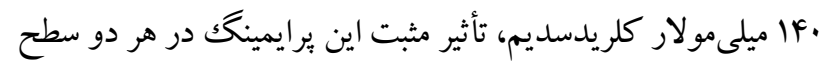

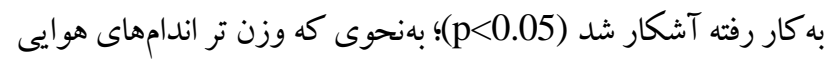

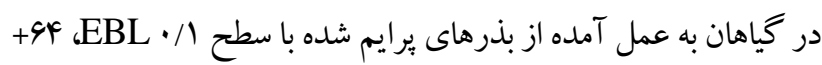

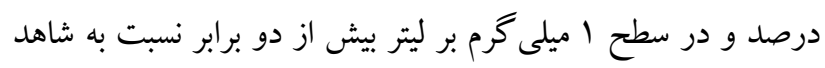

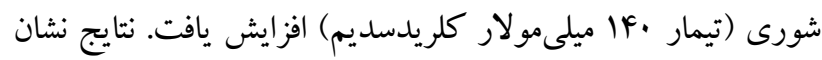

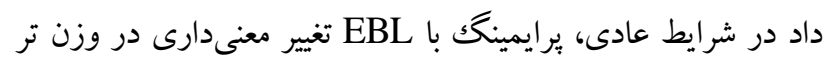

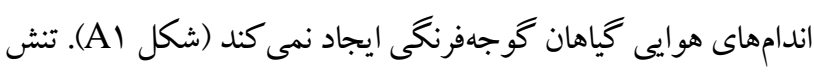
شورى از وزن تر ريشها نيز بهنحو معنى دارى كاست (p)

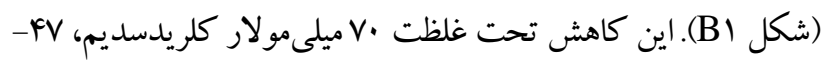

تنش شورى از سه سطح كلريدسديم (صفر، ·Vو ·fl ميلى مولار)

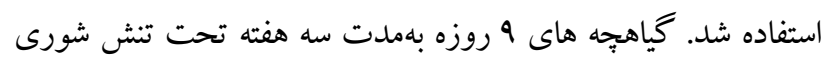

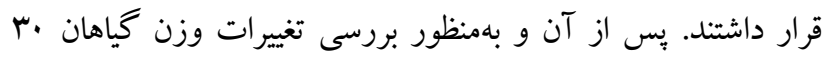

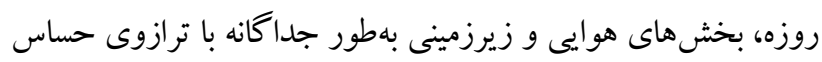

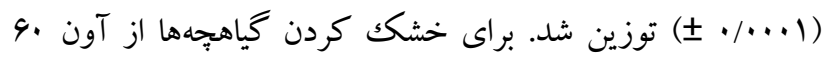

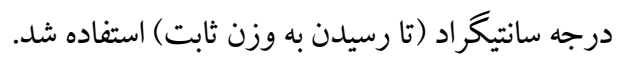

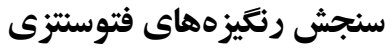

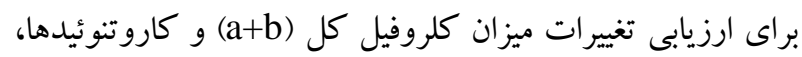

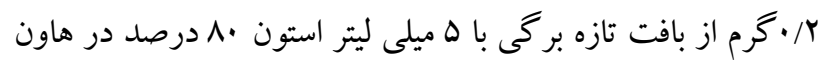

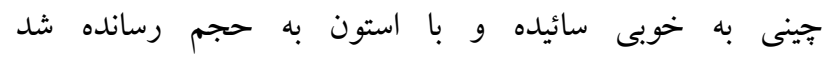
(Lichtenthaler \& Buschmann, 2001) سانتريفوز شده و سبس شدت جذب محلول شفاف رويى با دستگاه

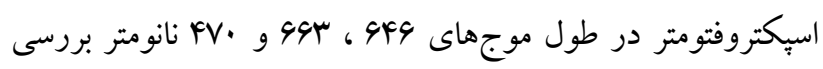

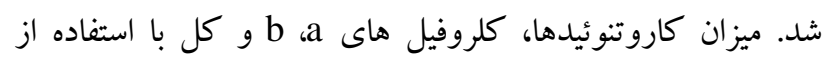
روابط زير محاسبه شد: - ماند

Chl. a $\left(\mathrm{mg}^{-\mathrm{ml}^{-1}}\right)=12.5 \mathrm{~A}_{663.2}-2.79 \mathrm{~A}_{646.8}$

Chl. b $\left(\mathrm{mg}^{-\mathrm{ml}^{-1}}\right)=21.51 \mathrm{~A}_{646.8}-5.1 \mathrm{~A}_{663.2}$

Chl. Total $\left(\mathrm{mg} \cdot \mathrm{ml}^{-1}\right)=\mathrm{Chl} . \mathrm{a}+\mathrm{Chl} . \mathrm{b}$

Car. $\left(\mathrm{mg} \cdot \mathrm{m}^{-1}\right)=\left[\left(1000 \mathrm{~A}_{470}\right)-(1.8 \mathrm{Chl}\right.$. a) - (85.2Chl. b)]/198

سنجش ثرولين آزاد

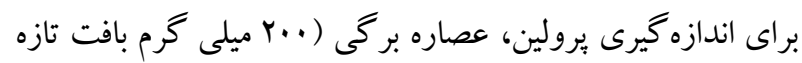

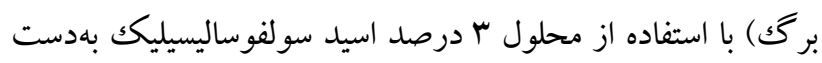
آهد (Bates et al., 1973). با استفاده از معرف نين هيدرين و

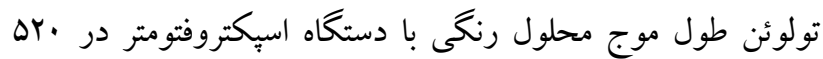

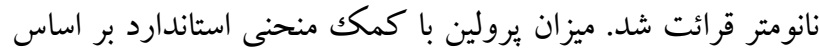
ميكرومولار بر خرم وزن تر محاسبه شد. اندازهيرى نشت الكتروليتى غشاء

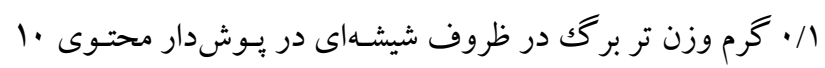

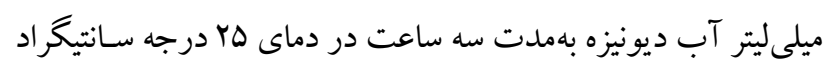

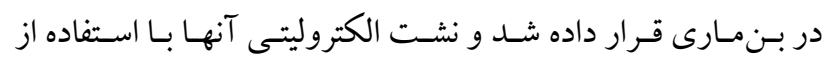
هدايتسنج الكتريكى اندازه گيرى شد (C)

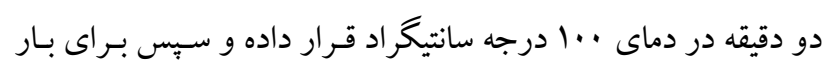

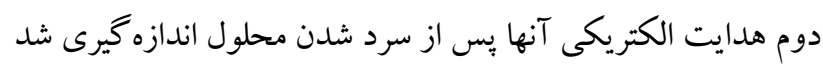

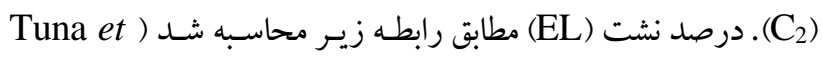
:(al., 2008

$\% \mathrm{EL}=\mathrm{C}_{1} / \mathrm{C}_{2} \times 100$ 
ميلىمولار، بيش از FV درصد نسبت به شاهد بود. تحت تنش شورى،

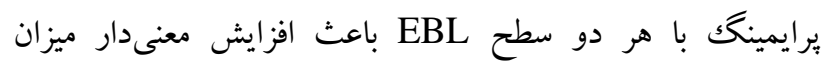

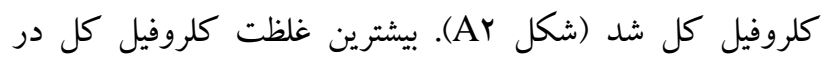

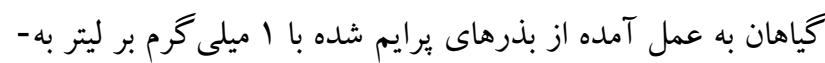

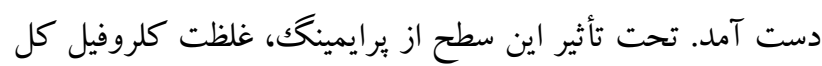

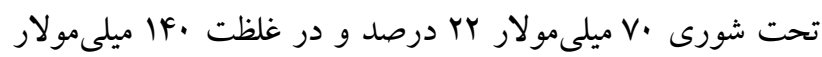

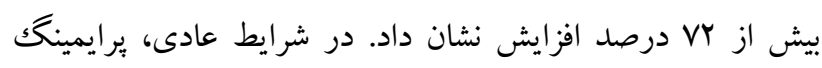

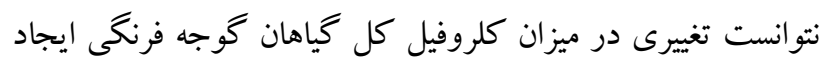
كند (شكل Ar). تنش شورى باعث كاهش معنىدار غلظت كاروتنوئيدها نسبت به

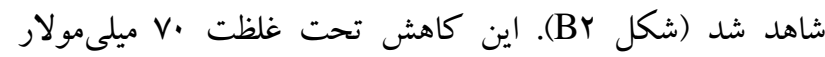

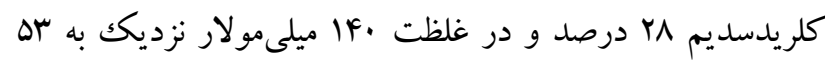

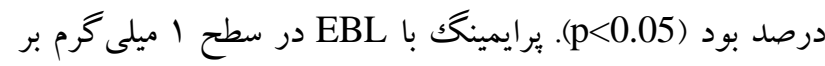

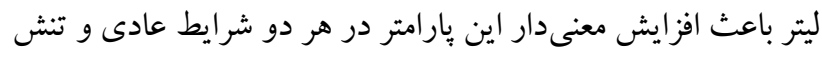

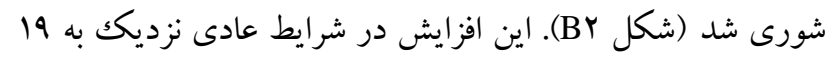

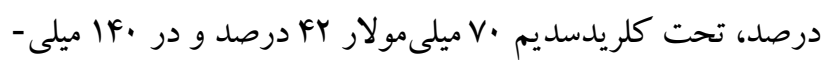
مولار دو برابر نسبت به شاهد مربوط به خود بود. در شرايط عادى و

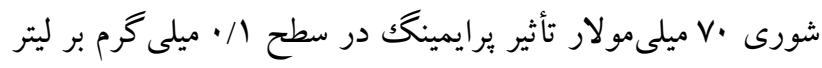

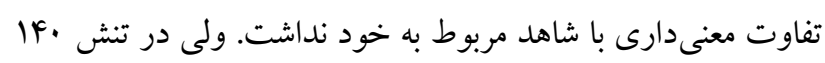

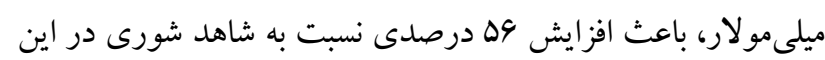

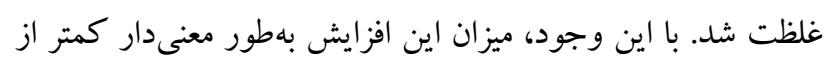

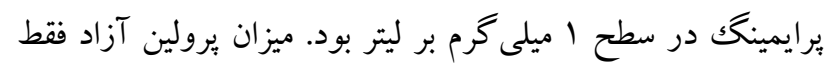

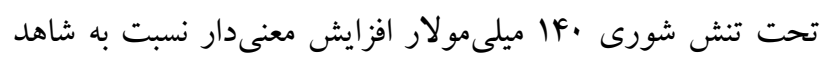

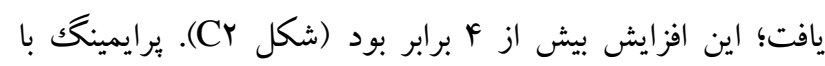
EBL

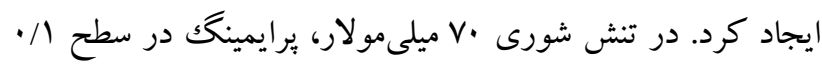

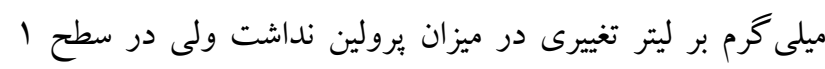

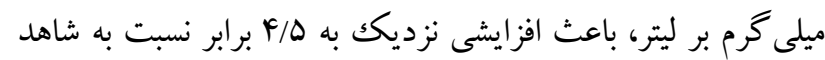

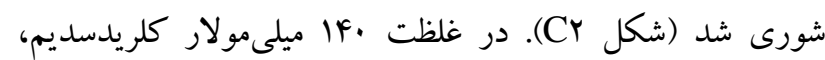

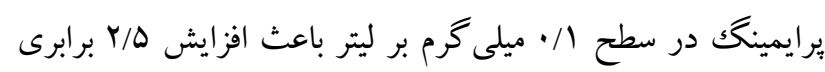

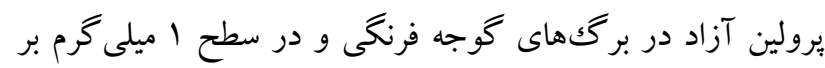

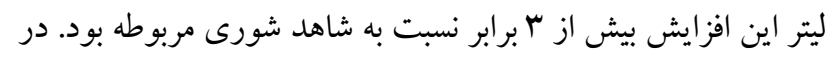

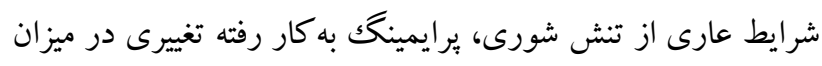

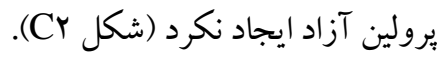

درصد و در سطح ·1f ميلىمولار 91- درصد بود. برايمينك با EBL در هر دو سطح باعث افزايش معنىدار وزن تر ريشهها شد (1) (p0.05).

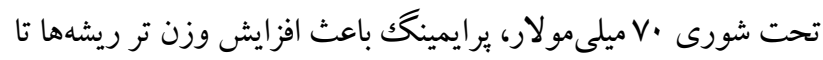

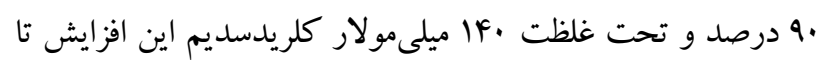

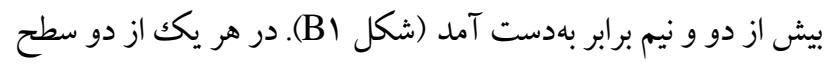

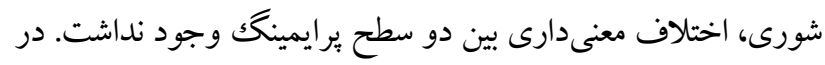

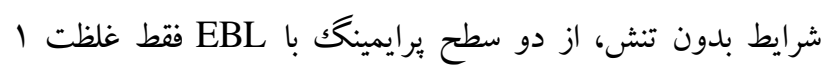

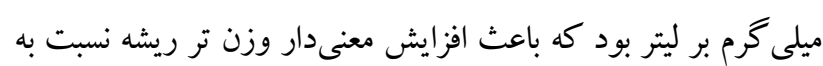

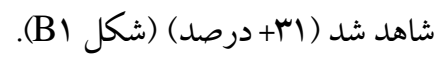

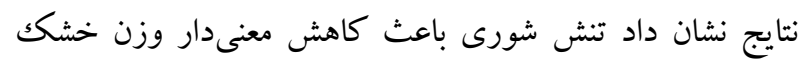

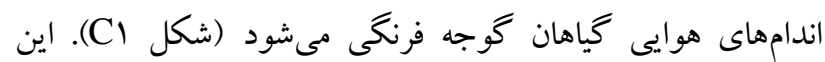

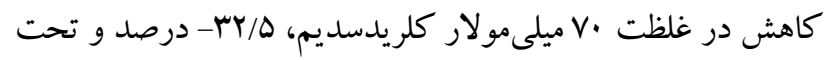

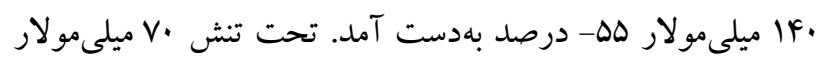

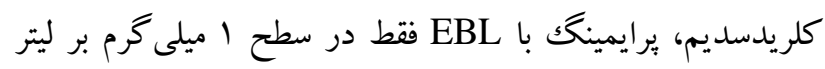

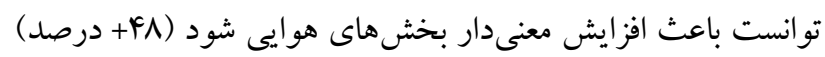

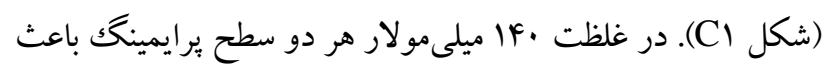

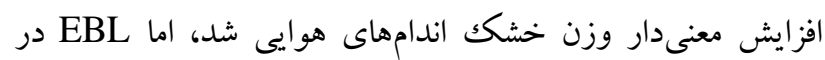

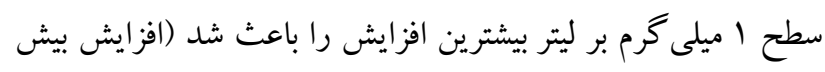

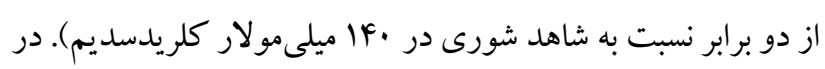

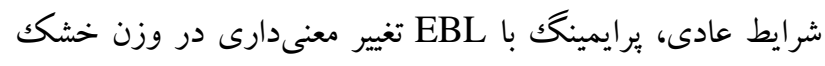

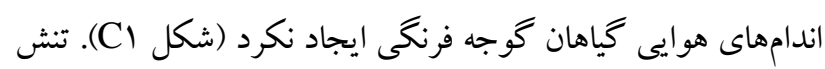

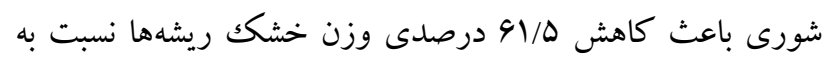

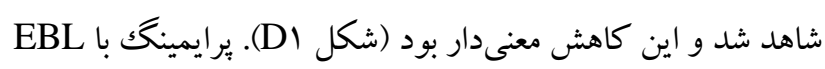

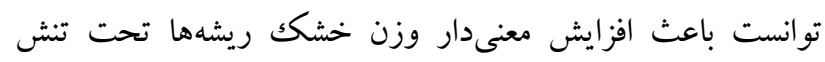

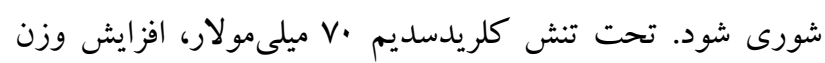

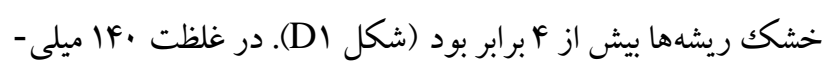

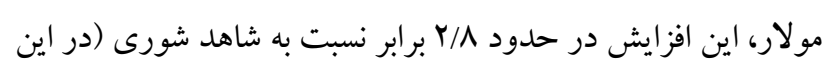

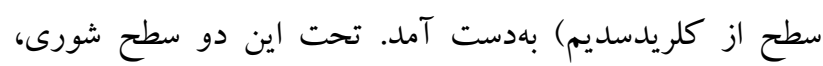

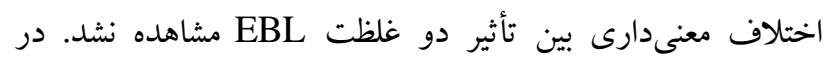

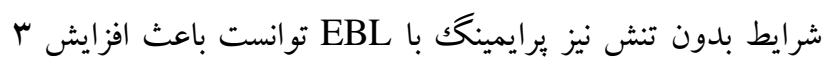

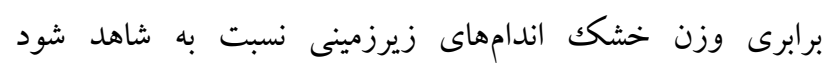

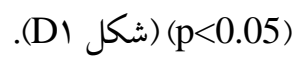

نتايج نشان داد تنش شورى در هر دو سطح، از ميزان كلروفيل كل

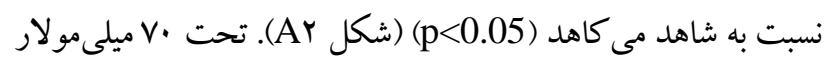

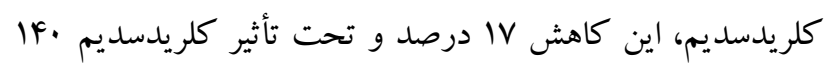


(B)

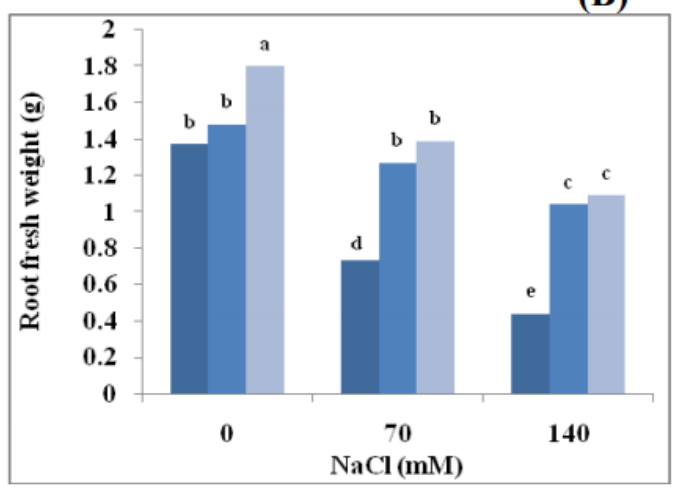

(D)

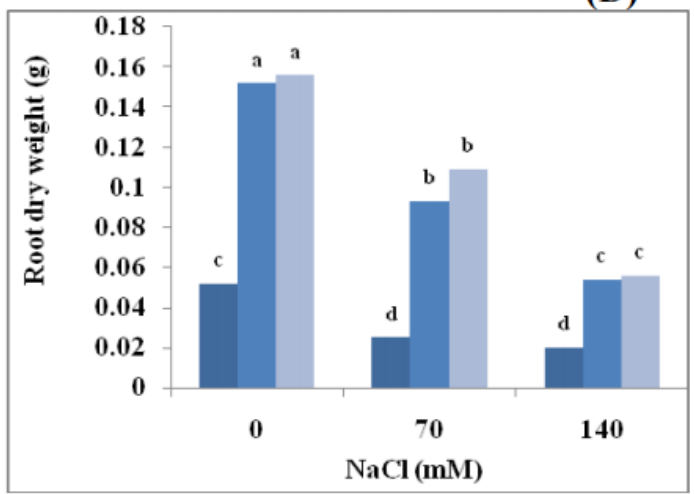

(A)

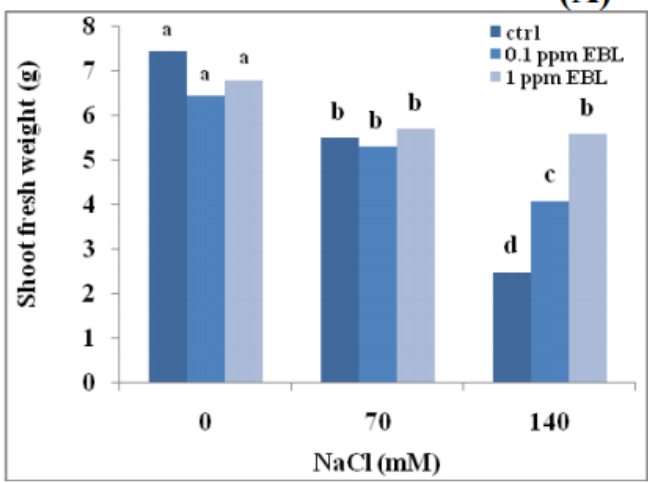

(C)

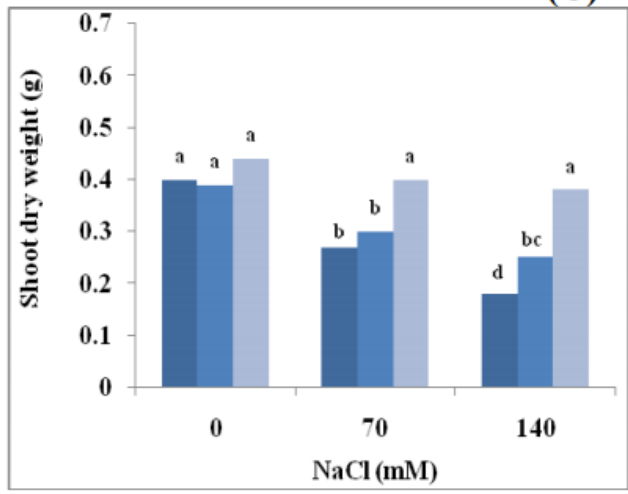

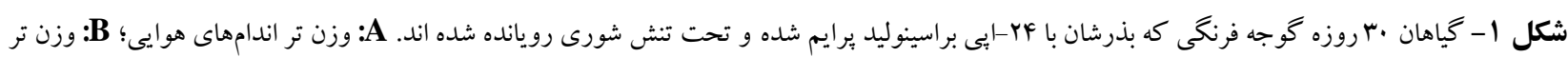

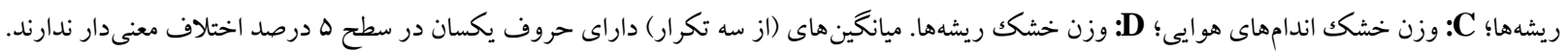

Fig. 1. 30-day-old Lycopersion esculentum plants whose seeds were primed with 24-epibrassinolide and grown under salt stress. A :Shoot fresh weight; $\mathbf{B}$ :Root fresh weight; $\mathbf{C}$ :Shoot dry weight; $\mathbf{D}$ :Root dry weight. Means (three replicates) with the same letter are not significantly different at $\mathrm{p}<0.05$.

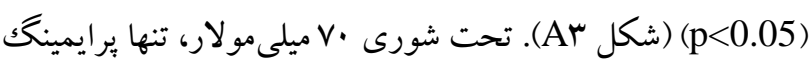

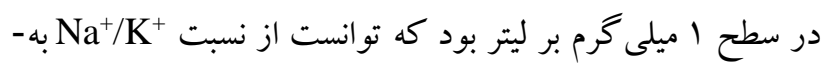

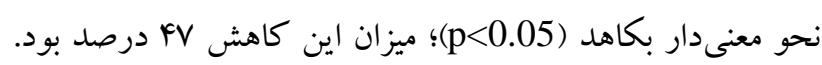

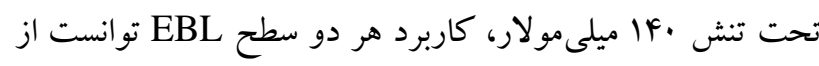
ميزان Na

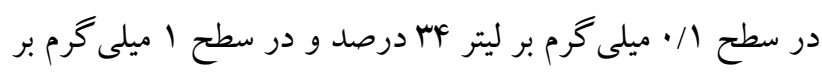

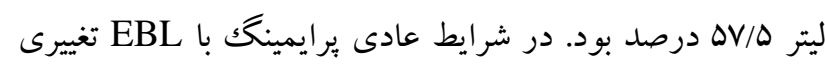
در ميزان

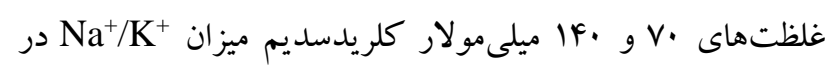

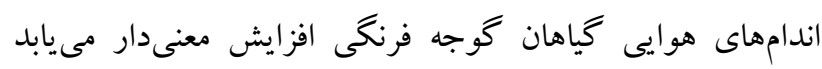

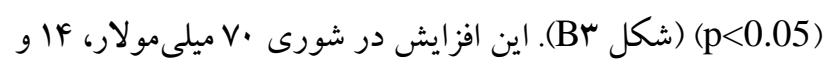

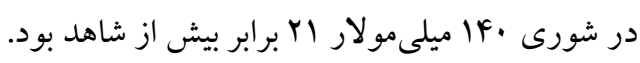

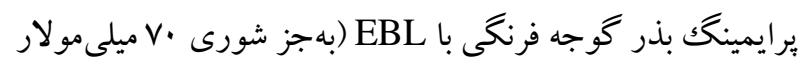

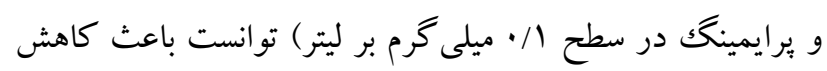
در اندامهاى هوايى گياهان گوجه فرنكى شود (شكل

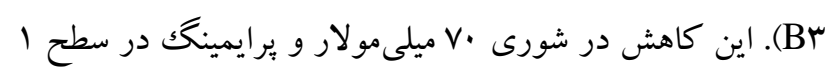

تحت تنش شورى، نشت الكتروليتى غشاء افزايش معنىدار نسبت به

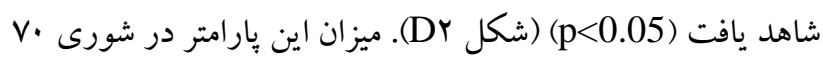

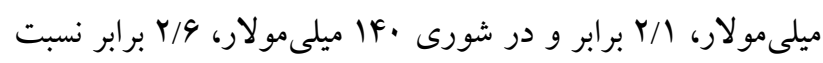

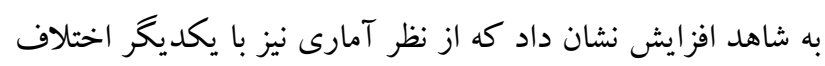

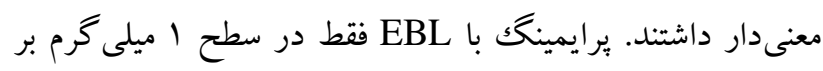

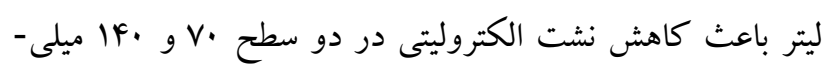

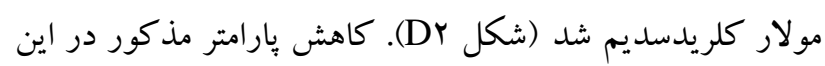

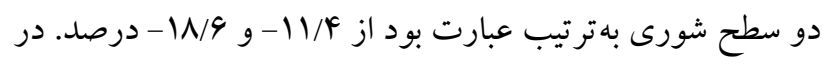

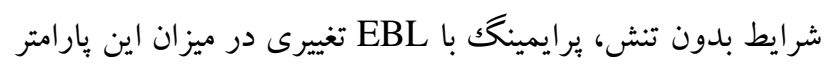
بهدنبال نداشت (شكل Dr)

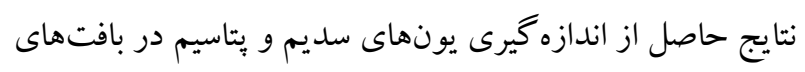
ريشه كوجه فرنكى نشان داد كه تحت تنش شورى ميزان

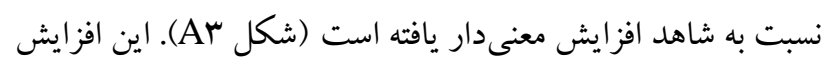

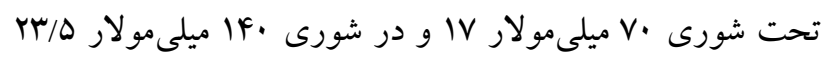

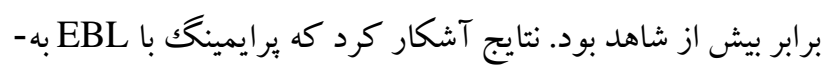

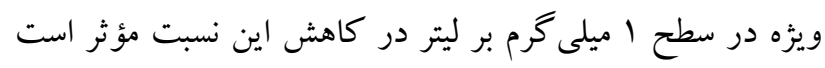


(B)

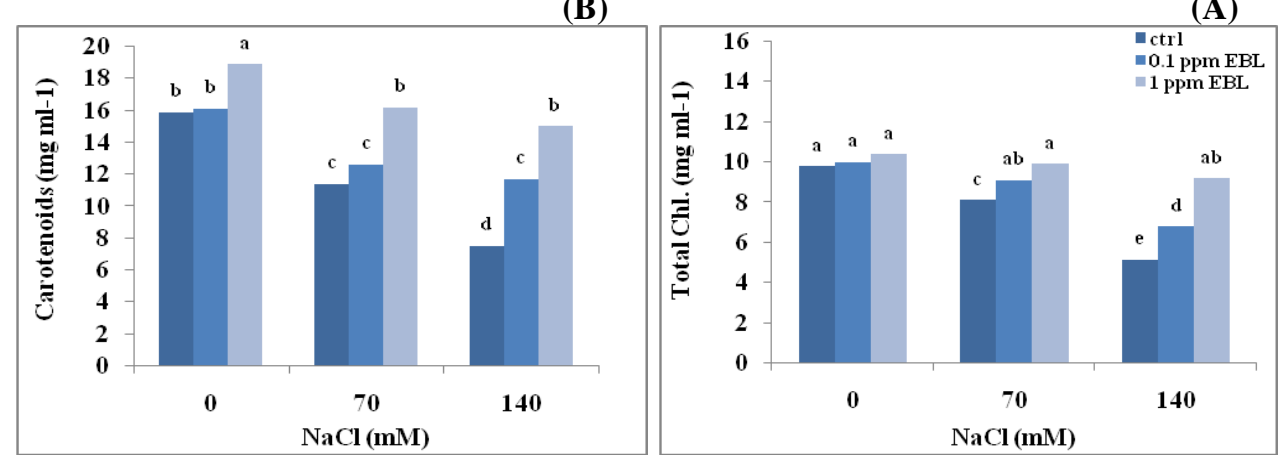

(D)
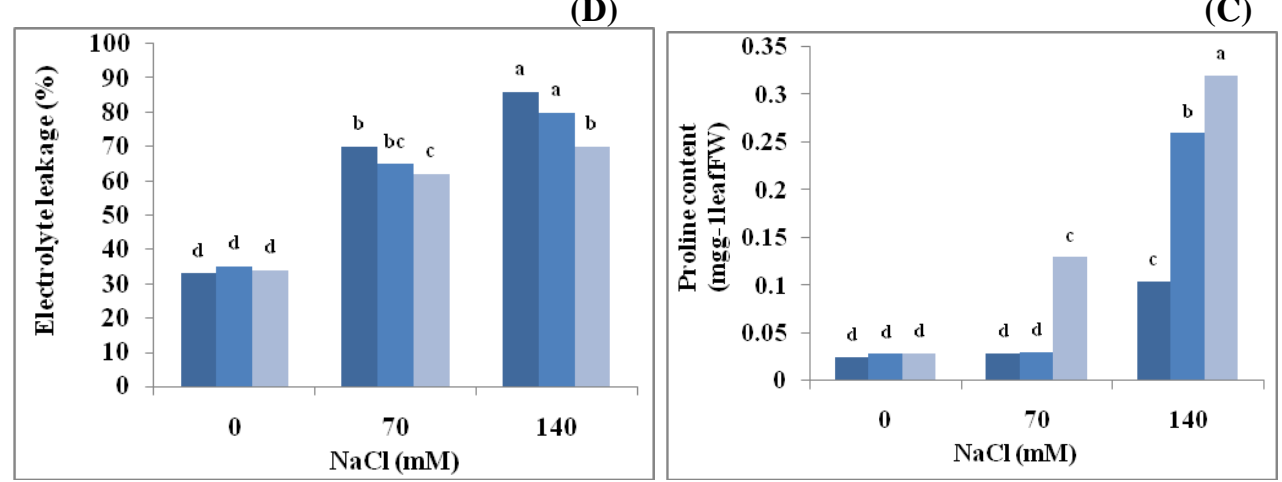

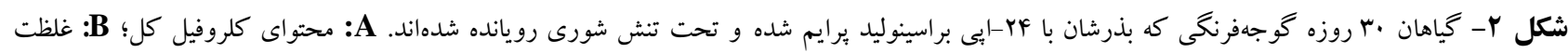

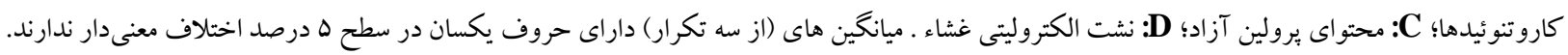

Fig. 2. 30-day-old Lycopersicon esculentum plants whose seeds were primed with 24-epibrassinolide and grown under salt stress. A :Total chlorophyll content; $\mathbf{B}$ :Carotenoids concentration; $\mathbf{C}$ :Free proline concentration; $\mathbf{D}$ :Electrolyte leakage. Means (three replicates) with the same letter are not significantly different at $\mathrm{p}<0.05$.

كياهان بوده است (Divi et al., 2010; Abbas et al., 2013).

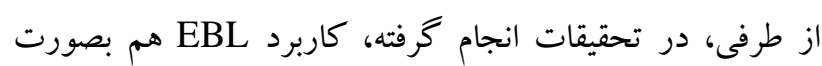

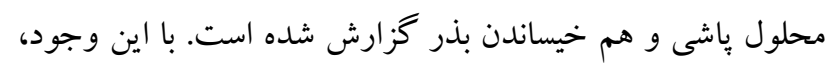

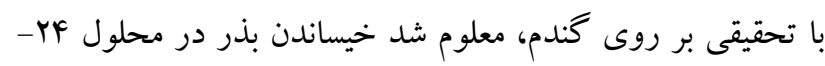

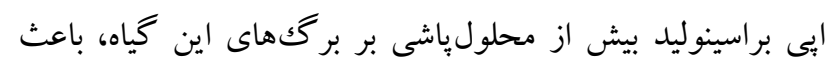

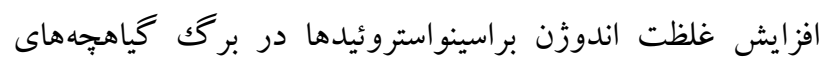

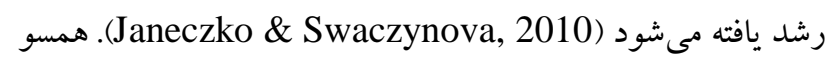
با جنين نتيجهاى، در تحقيق حاضر نيز برايمينك بذر بـ با EBL تحت بر بـى قرار خرفت. در تحقيقات انجام يافته هيج كاه به يكك غلظت بهينه ثابت براى

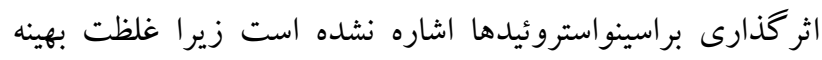

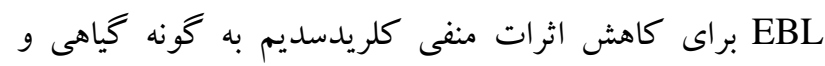

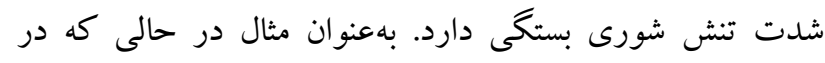

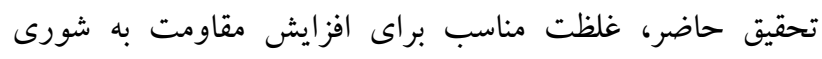

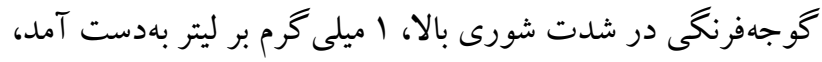

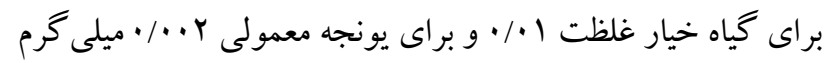

ميلى گرم بر ليتر برابر بود با •ه درصد (نسبت به شاهد شورى

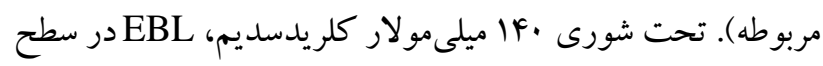

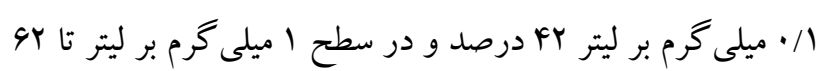
درصد از ميزان اين بارامتر كاست؛ اين تفاوت اختلاف آمارى نيز

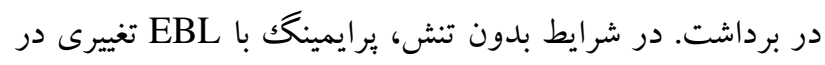
ميزان اين بارامتر ايجاد نكرد (شكل سر برد).

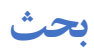

كياهان معمولا تحت تأثير عوامل نامطلوب محيطى نظير خشكى

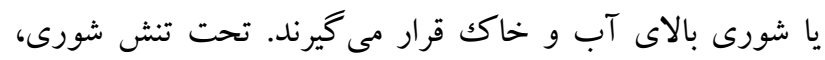
رشد و نمو كياه بهدليل كمبود آب (ناشى از اثرات اسمزى لئى كلريدسديم) و سميت يونهايى خاص (ماند ازدياد

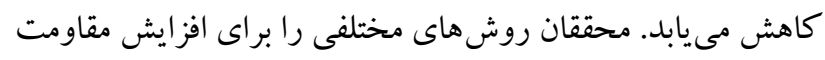
به شورى و بهبود رشد گياه در جنين شرايطى به كار مى بندنداند.

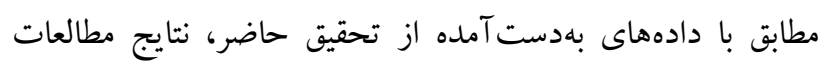

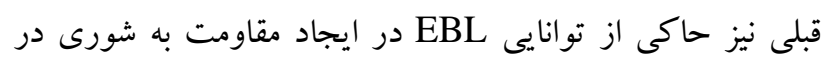


(B)

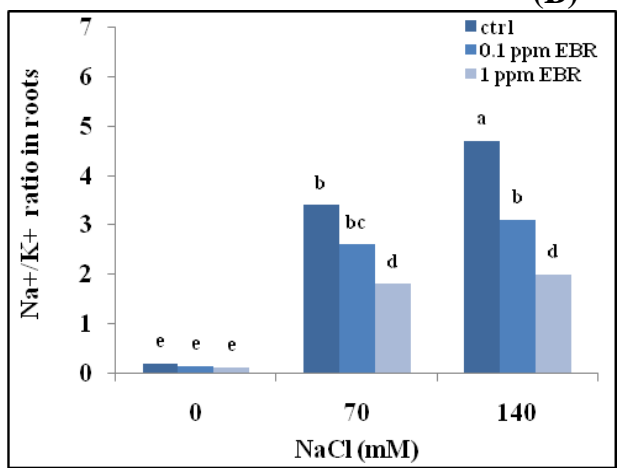

(A)

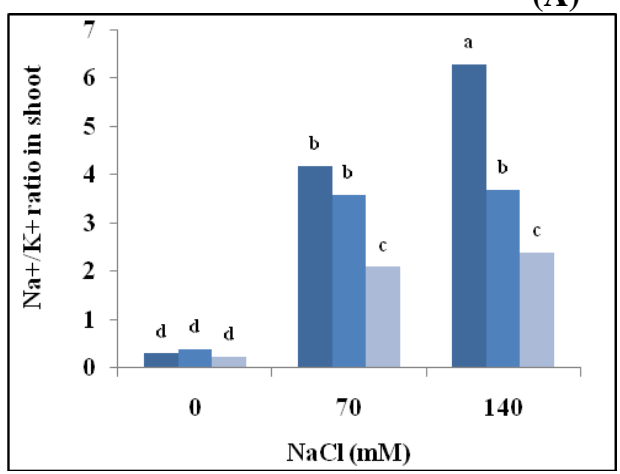

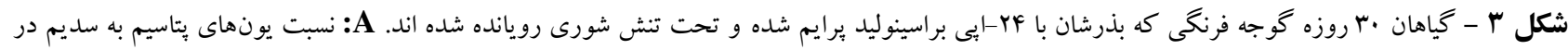

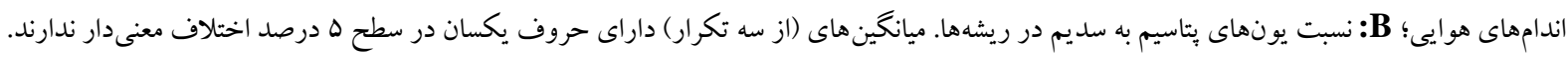

Fig. 3. 30-day-old Lycopersicon esculentum plants whose seeds were primed with 24-epibrassinolide and grown under salt stress. A : $\mathrm{K}^{+} / \mathrm{Na}^{+}$ratio in Shoot; $\mathbf{B}: \mathrm{K}^{+} / \mathrm{Na}^{+}$ratio in Root. Means (three replicates) with the same letter are not significantly different at $\mathrm{p}<0.05$.

اين تحقيق، EBL فسفريلاسيون تيروزينى يروتئينهاى مرحله تاريكى فتوسنتز را خاموش كرده و از اين طريق باعث بهبود فعاليت

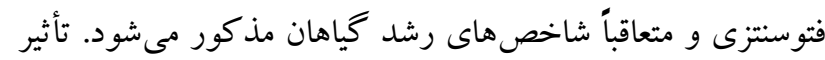

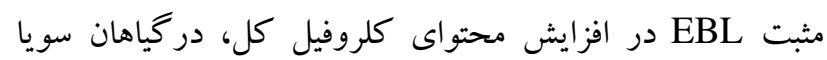
تحت شرايط غرقابى نيز گزارش شده است (Lu et al., 2006).

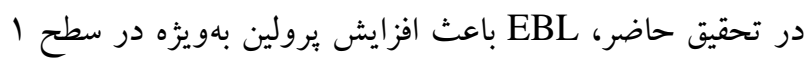

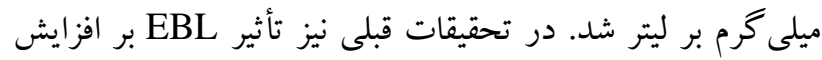

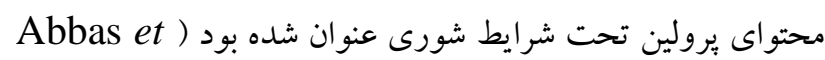
دفاع سه 2013 دفاع بيوشيميايى كياه، از اسيد آمينه برولين بهعنوان يكك اسموليت

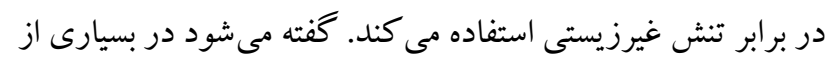

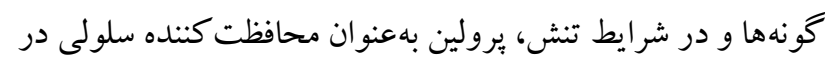

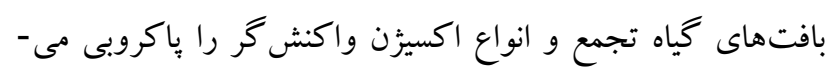

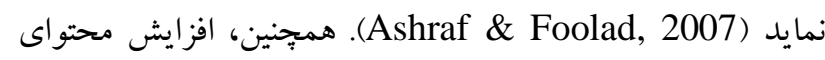

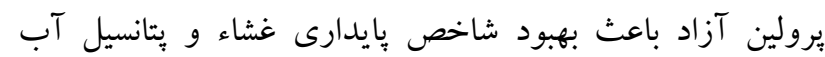
برگك مىشود (Rady, 2011; Hayat et al., 2010). تأثير

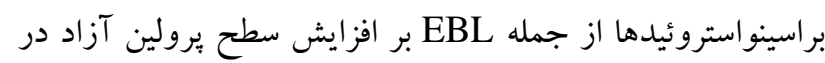

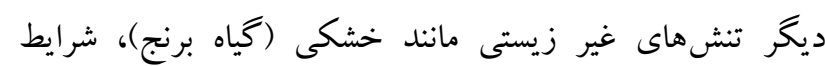

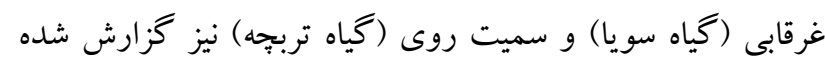
Lu et al., 2006; Farooq et al., 2009; ) رواسئ

.(Ramakrishna \& Rao, 2015

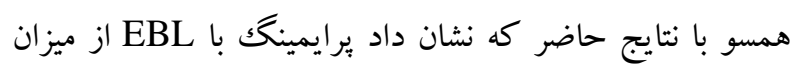

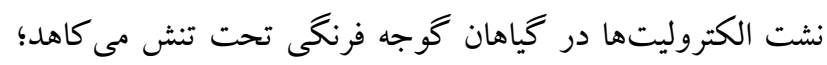

$$
\text { بر ليتر ززارش شده بود. }
$$

در تحقيق حاضر، در حضور كلريدسديم از ميزان بارامترهاى برد برد

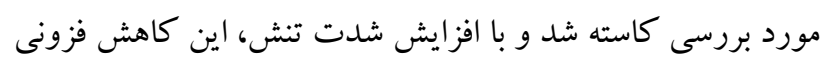

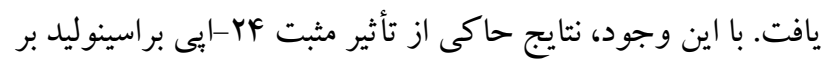

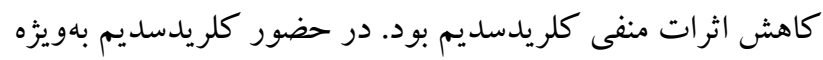

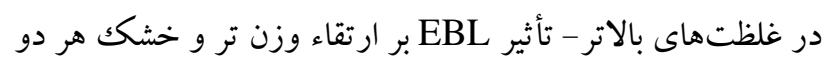

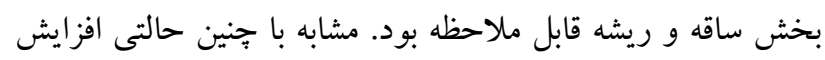

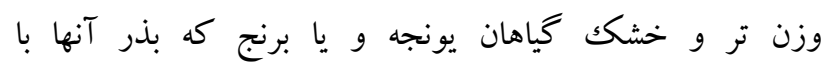
براسينواستروئيد برايم شده بود نيز گزارش شده است ( al., 2007; Sharma et al., 2013 شرايط بدون تنش، برايمينگك با EBL فقط بر افزايش وزن تر و

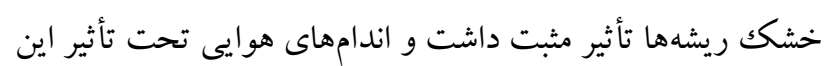
هو رمون قرار نخر فتند.

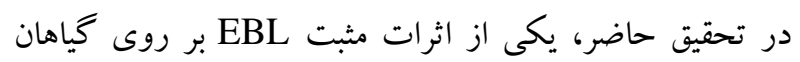

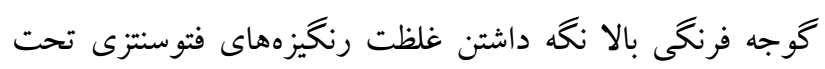

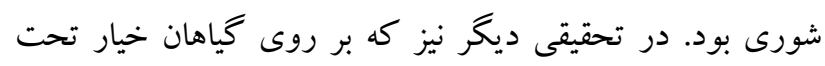

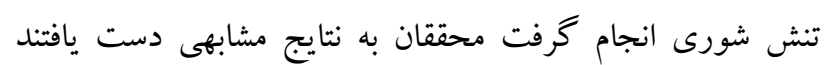

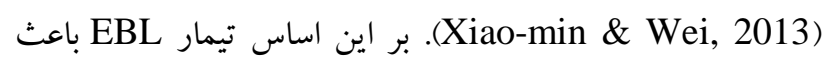
بالا نخه داشتن سرعت فتوسنتز تحت تنش شورى مى شود و به اين اين

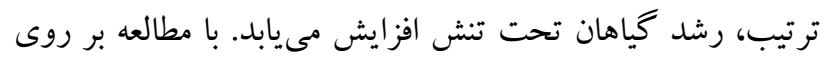

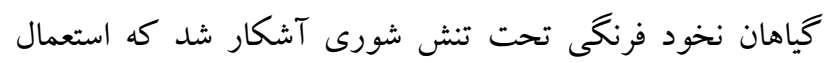
EBL سر گيرى رشد ساقه مى شود (Fedina, 2013). بر اساس يافته هاى 


\section{REFERENCES}

Abbas, S., Latif, H.H. and Elsherbiny, E.A. 2013. Effect of 24-epibrassinolide on the physiological and genetic changes on two varieties of pepper under salt stress conditions. - Pak. J. Bot. 45: 1273-1284.

Anuradha, S. and Rao, S.S.R. 2007. Effect of 24epibrassinolide on the growth and antioxidant enzyme activities in radish seedlings under lead toxicity. Indian J. Plant Physiol. 12: 396-400.

Ashraf, M. and Foolad, M.R. 2007. Roles of glycine, betaine and proline in improving plant abiotic stress resistance. - Environ. Exp. Bot. 59: 206-216.

Bajguz, A. and Hayat, S. 2009. Effects of brassinosteroids on the plant responses to environmental stresses. Plant Physio. Biochem. 47: 1-8.

Bates, L.S., Waldren, R.P. and Teare, I.D. 1973. Rapid determination of free proline for water-stress studies. - Plant and soil 39: 205-207.

Ding, H.D., Zhu, X.H., Zhu, Z.W., Yang, S.J., Zha, D.S. and Wu, X.X. 2012. Amelioration of salt-induced oxidative stress in eggplant by application of 24epibrassinolide. - Biol. Planta. 56: 767-770.

Divi, U.K., Rahman, T. and Krishna, P. 2010. Brassinosteroid-mediated stress tolerance in Arabidopsis shows interactions with abscisic acid, ethylene and salicylic acid pathways. - BMC Plant Biol. 10-151.

Farooq, M., Wahid, A., Basra, S.M.A. and Din, I.U. 2009. Improving the water relations and gas exchange with brassinosteroids in rice under drought stress. - J. Agro. Crop Sci. 195: 262-269.

Fedina, E.O. 2013. Effect of 24-epibrassinolide on pea protein tyrosine phosphorylation after salinity action. - Russian J. Plant Physiol. 60: 351-358.

Gomes, M.M.A. 2011. Physiological effects related to brassinosteroid application in plants. In Brassinosteroids: A Class of plant hormone (pp. 193242). Springer Netherlands.

Hayat, S., Hasan, S.A., Yusuf, M., Hayat, Q. and Ahmad, A. 2010. Effect of 28-homobrassinolide on photosynthesis, fluorescence and antioxidant system in the presence or absence of salinity and temperature in Vigna radiata. - Environ. - Exp. Bot. 69: 105-112.

Janeczko, A. and Swaczynova, J. 2010. Endogenous brassinosteroids in wheat treated with 24epibrassinolide. - Biol. Planta. 54: 477-482.

Khripach, V., Zhabinskii, V. and de Groot, A. 2000. Twenty years of brassinosteroids: steroidal plant hormones warrant better crops for the XXI century. Ann. Bot. 86: 441-447.

Kumar, M., Sirhindi, G., Bhardwaj, R., Kumar, S. and Jain, G. 2010. Effect of exogenous $\mathrm{H}_{2} \mathrm{O}_{2}$ on antioxidant enzymes of Brassica juncea L. seedlings in relation to 24-epibrassinolide under chilling stress. - Indian J. Biochem. Biophys. 47: 378-382.

Lichtenthaler, H.K. and Buschmann, C. 2001. Chlorophylls and carotenoids: Measurement and characterization by UV-VIS spectroscopy. In: Current protocols in food analytical chemistry, F4.3.1-F4.3.8. John Wiley and Sons, Inc. New York.
Lيخر گزارشات نيز نشان دهنده جنين تأثيرى بود ( Lئ 2006; Ding et al., 2012 همه مربوط به كاهش توليد سوبراكسايد و محتواى $\mathrm{H}_{2} \mathrm{O}_{\mathrm{N}} \mathrm{O}_{\mathrm{N}}$ نتيجه افزايش انسجام و ويايدارى غشاءهاى سيتويلاسمى دانستهاند Zhang et al., 2007). مشابه با نتايج بررسى حاضر بيرامون تأثير EBL بر روى نسبت مورد گياهان بادمجان تحت تنش شورى نيز گزارش شده است كه EBL آن هنوز مشخص نيست (Ding et al., 2012). بهور كلى مى توان نتيجه گيرى كرد دادههاى مقاله حاضر نشان

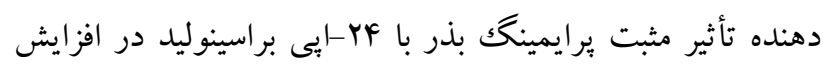
تحمل گياه گوجه فرنكى به تنش شورى در مرحله گياه كامل است. بر اين اساس، مكانيسم اين فر آيند مىتواند با افزايش غلظت يرولين آزاد و رنخيزههاى فتوسنتزى و نيز كاهش درصد نشت إنت الكتروليتها و نسبت Na $\mathrm{Na}^{+} / \mathrm{K}^{+}$ مر تبط باشد.

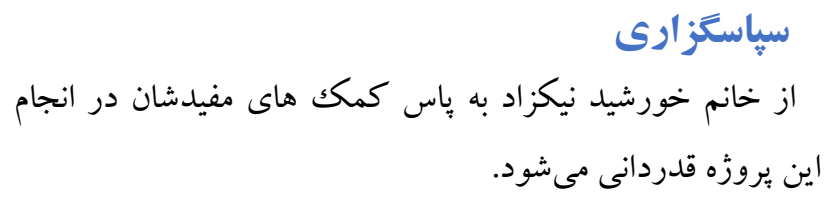


Lu, X., Chen, Y., Gong, W. and Chen, Y. 2006. Effect of brassinolide on the seedling growth and waterlogging resistance of soybean. - Chinese Agri. Sci. Bul. 23: 37-38.

Mahesh, B., Parshavaneni, B., Ramakrishna, B. and Rao, S.S.R. 2013. Effect of brassinosteroids on germination and seedling growth of radish (Raphanus sativus L.) under PEG-6000 induced water stress. - American J. Plant Sci. 4: 2305-2313.

Rady, M.M. 2011. Effect of 24-epibrassinolide on growth, yield, antioxidant system and cadmium content of bean (Phaseolus vulgaris L.) plants under salinity and cadmium stress. - Sci. Hort. 129: 232-237.

Ramakrishna, B., and Rao, S.S.R. 2015. Foliar application of brassinosteroids alleviates adverse effects of zinc toxicity in radish (Raphanus sativus L.) plants. -Protoplasma 252: 665- 677.

Shahid, M.A., Pervez, M.A., Balal, R.M., Mattson, N.S., Rashid, A. and Ahmad, R. 2011. Brassinosteroid (24epibrassinolide) enhances growth and alleviates the deleterious effects induced by salt stress in pea (Pisum sativum L.). - Australian J. Crop Sci. 5: 500510.

Sharma, I., Ching, E., Saini, S., Bhardwaj, R. and Pati, P.K. 2013. Exogenous application of brassinosteroid offers tolerance to salinity by altering stress responses in rice variety Pusa Basmati-1. - Plant Physiol. Biochem. 69: 17-26.

Tuna, A.L., Kaya, C., Higgs, D., Murillo-Amador, B., Aydemir, S. and Girgin, A.R. 2008. Silicon improves salinity tolerance in wheat plants. - Environ. Exp. Bot. 62: 10-16.
Xi, Z., Wang, Z., Fang, Y., Hu, Z., Hu, Y. and Deng, M. 2013. Effects of 24-epibrassinolide on antioxidation defense and osmoregulation systems of young grapevines ( $V$. vinifera L.) under chilling stress. Plant Growth Regul. 71: 57-65.

Xiao Jian, X., Zhang, Y., Wu, J.X., Wang, J.T., Zhou, Y.H., Shi, K., Yu, Y.L. and Yu, J.Q. 2009. Brassinosteroids Promote Metabolism of Pesticides in Cucumber. - J. Agri. Food Chem. 57: 8406-8413.

Xiao-min, L.U. and Wei, Y.A.N.G. 2013. Alleviation effects of brassinolide on cucumber seedlings under $\mathrm{NaCl}$ stress. - Yingyong Shengtai Xuebao 24: 24-30.

Zhang, S., Hu, J., Zhang, Y., Xie, X.J. and Knapp, A. 2007. Seed priming with brassinolide improves lucerne (Medicago sativa L.) seed germination and seedling growth in relation to physiological changes under salinity stress. - Crop and Pasture Sci. 58: 811815 .

$$
* * * * *
$$

How to cite this article:

Gholipoor, K. and Roshandel, P. 2019. Effects of seed pretreatment with 24-brassinolide on physiological and biochemical characters in tomato plants under salt stress. - Nova Biol. Reperta 5: 449-457.

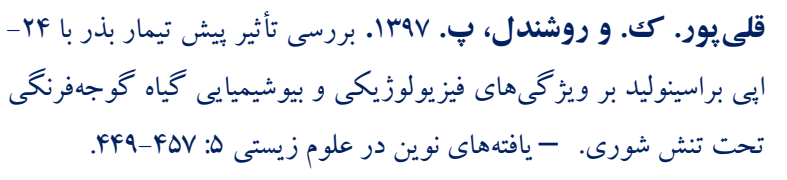

